\title{
The Usage of Internet Banking Service among Higher Learning Students in Malaysia
}

\author{
Etri Ernovianti, Nik Kamariah Nik Mat", Umar Kassim, Rashdan Rashid, Mai Syaheera Meor Shaari
}

Othman Yeop Abdullah Graduate School of Business, Universiti Utara Malaysia, Sintok, 06010, Malaysia

\begin{abstract}
Today, the advancement of internet has provided an opportunity for banking institution in introducing new financial innovations. One of the emerging financial innovations introduced by banking institution is online banking. This study adopts a technology acceptance model (TAM) to investigate factors that determine an individual's intention to use online banking by bank customers among higher learning students in Malaysia. The additional of TAM includes usefulness, ease of use, credibility, self-efficacy, compatibility and intention to use. By using simple random sampling, one hundred and seventy college students from university campuses in Tuanku Syed Sirajuddin Polytechnic will took part in the survey. Data was collected via questionnaires; the constructs Perceived usefulness and computer self-efficacy with three items were adapted from Wang et al. (2003). Perceived ease of use with four items was adapted from Nysveen et al. (2005). Perceived credibility with two items were adapted from Pikkarainen et al. (2004). Behavioral intention with two items was adapted from Venkatesh (2000). The data were analyzed using Structural equation modeling (SEM) using AMOS 18. Understanding what influences users to accept internet banking can be beneficial to banks, system developers and marketing practitioners in developing and marketing internet banking services that will be acceptable by the target market. The research finding shows that there is significant relationship between self efficiency towards intention to use of internet banking.
\end{abstract}

Keywords Internet Banking, Intention to Use, Perceive of Usefulness, Ease of Use, Self Efficiency, Credibility, Online Banking

\section{Introduction}

The usage of Internet commercially in Malaysia began in 1990, when the Malaysian Institute of Microelectronic Systems (MIMOS, now MIMOS Berhad) launched Joint Advanced Integrated Networking or JARING, the first Malaysian Internet Service Provider (ISP). Two years later in 1992, Malaysian users gained easy access to the global Internet with the installation of a satellite link between Malaysia and the US. The tremendous growth of Internet in Malaysia has been the result of the support and backing from the Malaysian Government. The Malaysian Government has employed a range of policies to encourage Malaysian businesses to venture online. It has also invested in large projects such as the Multimedia Super Corridor (MSC), a $50 \mathrm{~km}$ area stretching north from the Kuala Lumpur International Airport which has attracted more than 900 local and International IT and communication companies.

From the previous study, according to Nelson and Richmond[1] internet banking service is defined as a transaction oriented system that enables a bank's customers

* Corresponding author:

drnikuum@gmail.com (Nik Kamariah Nik Mat)

Published online at http://journal.sapub.org/economics

Copyright (C) 2012 Scientific \& Academic Publishing. All Rights Reserved to engage in online banking activities. The service available through internet banking can vary but typically include informational account access (view balance and past transaction). Malik[2] also argue the use of technology to communicate instructions and receive information from a financial institution where an account is held. However, using internet technology to access any activities or services from banks website through a public or private networks could be suitable definition for the internet banking services for the current study from past definition this study. Therefore, the purpose of this study is to investigate factors usage of internet banking service among higher learning students in Malaysia.

\section{Literature Review and Hypotheses Development}

In this study, the underpinning theory used is TAM. TAM being used by Norazah, Ramayah, Norbayah[3] to examine the relationship between perceived ease of use, cognitive absorption (CA), perceived usefulness (PU), and fashion involvement (FI) with students' buying intentions. PU, product search, online experience, FI were positively related to online shopping behavior. Hainudin[4] examine the effect of TAM in internet banking system. 


\subsection{Intention to Use}

This construct was originated from the Theory of Reasoned Action (TRA) by[5].The construct is defined as "a measure of the strength of one's intention to perform a specified behavior"'[6]. Intention to use in ICT environment reflects the user's choice for actual use. Previous studies in information technology analyzing intention as determine factor of behaviour[7],[8],[9]. Technology Acceptance Model (TAM) is popular among IS researcher in identifying antecedents of usage, ease of use[6]. Early studies in e commerce using TAM as underpin theory[10].

\subsection{Perceived Usefulness}

These studies offer an insight for the author to further investigate the following hypothesis:

H1: Perceived usefulness will have a positive effect on behavioral intention to use the Internet banking systems.

H2: Perceived usefulness will have a positive effect on self efficiency to use the Internet banking systems.

H3: Perceived usefulness will have a positive effect on credibility to use the Internet banking systems.

Prior studies indicate that there is a positive relationship between perceived usefulness and usage intention[11],[12],[13],[14],[15].This is also supported by Venkatesh et al.[15], Hernandez et al.,[16], and Weisberg et al.,[17]. Previous study by Chiu et al.,[13] has revealed that Perceived Usefulness positively influence online purchase intention but negatively influence attitudes. Hainudin[4] found that perceived usefulness and perceived ease of use significantly determine behavioral intention in internet banking system.

\subsection{Perceive Ease of Use}

By extending these study results, the following hypotheses for Internet banking:

H4: Perceived ease of use will have positive effect on behavioral intention to use the Internet banking systems.

H5: Perceived ease of use will have positive effect on credibility to use the Internet banking systems.

H6: Perceived ease of use will have positive effect on self efficacy to use the Internet banking systems.

Previous studies have shown that there is a positive relationship between Perceived Ease of Use and usage intention (Guriting \& Ndubisi,[18]; Luarn \& Lin,[11]; Kleijnen, et al.,[19]; Wang, et al.,[14] and Ramayah, et al.,[20]. Guriting \& Ndubisi[18] found that perceived ease of use had a significantly positive effect on behavioral intention to use online banking in Malaysia. Furthermore, Luarn \& Lin[11] also found that there exists a positive causality between Perceived Ease of Use and usage intention. Hainudin[4] and Wang et al.[14] found that PEOU has a positive effect on behavioral intention to use the Internet banking.

\subsection{Self Efficiacy}

H7: Perceived computer self efficacy will have positive effect on behavioral intention to use the Internet banking systems.

There is empirical support for the causal relationship between perceived self-efficacy and behavioural intention[21],[15] and[22]. In a recent study, Luarn \& Lin[11] found that perceived self-efficacy had a significantly positive influence on behavioural intention to use an IT system. The result is also corroborated by the study of Wang et al.[14] who found that computer self-efficacy had a significantly positive influence on behavioural intention.

\subsection{Perceived Credibility}

H8: Perceived credibility will have positive effect on behavioral intention to use the Internet banking systems.

Hainudin[4] found a positive effect on behavioral intention to use the internet banking system. According to a previous study by Wang, et al.,[14] security is one of the two important dimensions in perceived credibility. Perceived Credibility is usually impersonal and relies on the reputation, information and economic reasoning[23]. Furthermore, Wang, et al[14] found that perceived credibility is significantly related to the acceptance of the technology involved in internet banking.

\section{Methodology}

This study is interested in accessing information from customers. Therefore, 3,128 Polytechnic Tuanku Syed Sirajuddin students based on the total enrollment in Jan 2010 was the population for the study. A convenience sampling was utilized to survey about 250 students at the Polytechnic Tuanku Syed Sirajuddin. The reasons of using this sampling type because it offers an easy way to obtain the raw data for the further analysis and it saves times and costs since the respondents can be randomly selected. From 250 questionnaires being distributed, 170 were returned.

Data was collected via questionnaires that were administered to students during classes. Participation was voluntary and confidential. The constructs were measures by using seven point scales. The questionnaire items were adapted from different sources. Perceived usefulness with three items were adapted from Wang et al.[14]. Perceived ease of use with four items was adapted from[24]. Perceived credibility with two items were adapted from[25]. Behavioral intention with two items was adapted from[15]. Finally, computer self-efficacy with three items was adapted from Wang et al.[14].

\section{Results}

Participants in the study comprised $45.56 \%$ male and $54.44 \%$ female. Majority of the respondents were female which is 92 respondents while male is 77 respondents make the grand total respondents are 169. Majority of the respondents were Malay (110) followed by Indian (30), 
Chinese (24) and others (5). In addition, these figures consist of $65.09 \%, 17.75 \%, 14.2 \%$ and $2.96 \%$ for Malay, Indian, Chinese and others respectively as presented in Table 1.

This study used the structural equation modeling (SEM) for hypotheses testing. In these results, the structural model presented here indicates adequate fit with the observed data, compared with the suggested fit criteria.

Table 3. Results of the model goodness-of-fit

\begin{tabular}{|ccc|}
\hline Fit Index & $\begin{array}{c}\text { Recommen } \\
\text { ded criteria }\end{array}$ & $\begin{array}{c}\text { Results in } \\
\text { this study }\end{array}$ \\
\hline Chi-Square/Degree of freedom & $<3$ & 301.824 \\
P value & $>0.05$ & 0 \\
GFI (goodness-of-fit index & $>0.90$ & 0.852 \\
AGFI (adjusted goodness-of-fit index & $>0.90$ & 0.802 \\
CFI (comparative fit index) & $>0.90$ & 0.942 \\
RMR (root mean squared residual) & $<0.05$ & - \\
RMSEA (root mean squared error of & $<0.05$ & 0.075 \\
approximation) & $>0.90$ & 0.929 \\
NFI (Normative Fit Index) & & \\
\hline
\end{tabular}

\subsection{Tests of Hypotheses}

Table 3 presents results from the path analysis of the combined hypotheses. The first, second and third hypotheses proposed that usefulness would be a positive predictor of intention, self efficiency and credibility. The path for $\mathrm{H} 1$ was not significant $(\beta=0.390, p=0.371)$, so as the path for $\mathrm{H} 2$ was not significant $(\beta=0.364, p=0.302)$. But, $\mathrm{H} 3$ was significant $(\beta=0.699, p=0.035)$. Thus, $\mathrm{H} 3$ were supported while $\mathrm{H} 1$ and $\mathrm{H} 2$ were not supported.

The fourth, fifth and sixth hypotheses proposed that ease of use would be a positive predictor of intention to use, credibility and self efficiency. The path for $\mathrm{H} 4(\beta=-0.276, \mathrm{p}$ $=0.319), \mathrm{H} 5(\beta=0.232, \mathrm{p}=0.459)$ and $\mathrm{H} 6 \quad(\beta=0.112, \mathrm{p}=$ 0.743 ) were insignificant respectively. Therefore Hypothesis 4, 5 and 6 were not supported.

The seventh and eighth hypotheses proposed self efficiency and credibility would be a positive predictor of intention to use internet banking toward the use of internet banking system. Only path for $\mathrm{H} 7,(\beta=0.280, \mathrm{p}=0.000)$ was significant while the path for $\mathrm{H} 8,(\beta=0.603, \mathrm{p}=0.154)$ was insignificant. Thus Hypotheses 7 was supported. Only Hypotheses 8 was not supported.

\section{Conclusions}

Based on the relationship between perceived ease of use and intention to use that show no significant effect is consistent with[25] and[26]. This result is inconsistent with[27]. The unexpected result due to the fact that the respondents are relative young whereby they can easily learn online banking.

The findings in the present study show that in Malaysia, intention to use Internet banking is predicted by self efficiency. The strong influence of self efficacy could reflect their importance to intention to use technology across culture because doing internet banking is not easy as internet surfing. Therefore, banks should concentrate on providing sufficient guidelines in their Internet banking services especially on youths and young adults who are more likely to be risk takers and love the comfort that Internet banking provides. In polytechnic, the introduction of diploma programmed in information technology during the late 2000 and e-commerce programmed which started in 2010 , may have had affected the perception of online banking and self efficacy among students nowadays. Furthermore, e-commerce course has also been introduced as a core course in Business Management programmed at polytechnics in the beginning of 2011. The programmed was aimed at strengthening students' cognition and understanding on online as well as promoting consciousness on legal rights in online trade.

Perceived credibility shows insignificant relationship which is inconsistent with previous studies by Hainudin[4] who claimed that perceived credibility was determinant of behavioral intention. Respondents' judgment on the privacy and security issues of internet banking is less due to higher self efficiency.

Table 4. Hypotheses Testing

\begin{tabular}{|c|c|c|c|c|c|c|}
\hline Hypothesis & Relationship & Standardized Beta & Standard Error & Critical Ratio & P-value & Decision \\
\hline $\mathrm{H}_{1}$ & Usefulness<---intention to use & 0.390 & 0.497 & 0.895 & 0.371 & Not supported \\
\hline $\mathrm{H}_{2}$ & Usefulness<---self efficiency & 0.364 & 1.402 & 1.033 & 0.302 & Not supported \\
\hline $\mathrm{H}_{3}$ & Usefulness<---credibility & 0.699 & 1.162 & 2.104 & 0.035 & Supported \\
\hline $\mathrm{H}_{4}$ & Ease of use<---intention to use & -0.276 & 0.078 & -0.997 & 0.319 & Not supported \\
\hline $\mathrm{H}_{5}$ & Ease of use<---credibility & 0.232 & 0.270 & 0.740 & 0.459 & Not supported \\
\hline $\mathrm{H}_{6}$ & Ease of use<---self efficiency & 0.112 & 0.336 & 0.328 & 0.743 & Not supported \\
\hline $\mathrm{H}_{7}$ & Self efficiency<---intention to use & 0.280 & 0.023 & 3.455 & 0.000 & Supported \\
\hline $\mathrm{H}_{8}$ & Credibility<---intention to use & 0.603 & 0.138 & 1.425 & 0.154 & Not supported \\
\hline
\end{tabular}


The findings could not be generalized for the whole Campuses of Northern region Institution of Malaysia because it was only conducted in the Tuanku Syed Sirajuddin Polytechnic only. This model has shown some interesting findings which could be applied for utilization in research on a bigger scale to include the whole of Malaysia Country. The study has provided the determinants that influence polytechnic students' intention to use internet banking in the future. This study also reflects the internet banking understanding from undergraduate point of view.

\section{ACKNOWLEDGEMENTS}

We would like to thank Prof Dr. Nik Kamariah Nik Mat and Sukma Pea for their helpful comments and assistance on an earlier version of this paper.

\section{REFERENCES}

[1] Nelson, P. and Richmond, W. (2007). Internet banking: gold mine or money pit?. Academy of Banking Studies Journal, 6 (1), 1-25.

[2] Malik, K. "Coordination of Technological Knowledge Flows in Firms." Journal of Knowledge Management 8, no. 2(2004) : 64-72. eScholarID:1b8960

[3] Norazah, M.S.;Ramayah, T. and Norbayah, M.S. (2008). Internet shopping acceptance Examining the influence of intrinsic versus extrinsic motivations. Direct Marketing: An International Journal, 2(2), 97-110.

[4] Hainudin, A. (2007). Internet Banking Adoption Among Young Intellectual. Journal of Internet Banking and Commerce, 12(3).

[5] Ajzen,I. \& Fishbein, M. Attitude-behavior relations: a theoretical analysis and review of empirical research \& psychological Bulletin, 84(5), 888-918, 1975.

[6] Davis, F. D. (1989). Perceived usefulness, perceived ease of use and end user acceptance of information technology. MIS Quartely, 13(3), 319-340.

[7] Liu C. Jack M. June L. Chun Y. Beyond concern: A privacy-trust-behavioral intention model of electronic commerce. Information \& Management 2004; 42: 127-142.

[8] Ajzen, I. 1991. "The Theory of Planned Behavior." Organizational Behavior and Human Decision Processes, 50(2): 179-211.

[9] Taylor, S. \& P. A. Todd. 1995. "Understanding Information Technology Usage: A Test of Competing Models." Information Systems Research, 6(2): 144-176.

[10] Gefen, D. and Straub, D. (1997). Gender differences in the perception and use of e-mail: an extention to the technology acceptance model. MIS Quarterly, 21(4), 389-400.

[11] Luarn, P., and Lin, H.H. (2005). Toward an understanding of the behavioural intention to use mobilebanking. Computers in Human Behaviour, 21, 873-891

[12] Cheong, J.H., and Park, M.C. (2005). Mobile internet acceptance in Korea. Internet Research, 15(2),125-140

[13] Chiu, Y.B., Lin, C.P., and Tang, L.L. (2005). Gender differs: Assessing a model of online purchaseintentions in e-tail service. International Journal of Service Industry Management , 16(5), 416-435

[14] Wang, Y.S., Wang, Y.M., Lin, H.H., and Tang, T.I. (2003). Determinants of user acceptance of internet banking: An empirical study. International Journal of Service Industry Management, 14(5),501-519.

[15] Venkatesh, V., and Morris, M.G. (2000). Why don't men ever stop to ask for directions: Gender,social influence and their role in technology acceptance and usage behavior. MIS Quarterly, 24(1),115-139.

[16] Hernandez, B., Jimenez, J. and Martin, M.J. (2011). Age, gender and income:do they really moderate online shopping behaviour? Online Information Review, 35(1), 113-133.

[17] Weisberg, J.; Te'eni, D. and Arman, L. (2011). Past purchase and intention to purchase in e-commerce: The mediation of social presence and trust. Internet Research, 21(1), 82-96.

[18] Guriting P, Ndubisi NO (2006). Borneo online banking: evaluating customer perceptions and behavioural intention. Manage. Res. News. 29 (1/2), 6-15.

[19] Kleijnen, M., Wetzels, M. and de Ruyter, K. (2004) Consumer Acceptance Of Wireless Finance, Journal of Financial Services Marketing, 8, 206-217.

[20] Ramayah T, Jantan, M., Noor M.N.M. and Ling, K.P. (2003) Receptiveness Of Internet Banking By Malaysian Consumers, Asian Academy of Management Journal, 8, 2, 1-29.

[21] Agarwal, R., and Karahanna, E. (2000). Time flies When You're Having Fun: Cognitive Absorption and Beliefs About Information Technology Usage. MIS Quarterly, 24(4), 665-694.

[22] Compeau, D.R., \& Higgins, C.A. (1995, June). Computer Self-Efficacy: Development of a Measure and Initial Test. MIS Quarterly, 19, (2), 189-211.

[23] Ba, S. and P.A. Pavlou, "Evidence of the Effect of Trust Building Technology in Electronic Markets: Price Premiums and Buyer Behavior," MIS Quarterly, Vol. 26, No. 3:243-268, 2002.

[24] Nysveen, H., Pedersen, P.E. and Thorbjornsen, H. (2005) Explaining Intention To Use Mobile Chat Services: Moderating Effects Of Gender, Journal of Consumer Marketing, 33, 5, 247-256.

[25] Pikkarainen, T.;Pikkarainen, K.;Karjaluoto, H. and Pahnila, S. (2004). Consumer acceptance of online banking: An extention of the technology acceptance model. Internet Ressearch, 14(3), 224-235.

[26] Chong, A.Y.L;Ooi, K.B;Lin, B. and Tan,B.I. (2010). Online banking adoption:an empirical analysis. International Journal of Bank MArketing, 28(4), 267-287.

[27] Maharsi, S., Mulyadi, Y., (2007), Faktor-faktor Yang Mempengaruhi Minat Nasabah Menggunakan Internet Banking Dengan Menggunakan Kerangka Technology Acceptance Model (TAM), Jurnal Akuntansi dan Keuangan,Vol. 9., No. 1, hal. 18-28, Universitas Kristen Petra Surabaya. 